\title{
MODEL ESTIMASI KARAKTERISTIK MODUL PHOTOVOLTAIC POL YCRYSTALLINE DAN MONOCRYSTALLINE 50 WP
}

\author{
Rusman Sinaga ${ }^{1 *}$, Marthen Dangu Elu Beily ${ }^{2}$ \\ 1,2 Jurusan Teknik Elektro Politeknik Negeri Kupang \\ Jalan Adisucipto Penfui Kupang Indonesia 85361 \\ "E-mail: sinagarusman@gmail.com
}

\begin{abstract}
Abstrak
Rasio elektrifikasi di Kabupaten Kupang masih 60\%. Rata-rata rumah tangga yang belum mendapatkan pasokan listrik berada di perdesaan terpencil yang sulit dijangkau oleh jaringan PLN. Alternatif yang paling baik dalam penyediaan sumber energi listrik di perdesaan Kabupaten Kupang yang belum terjangkau oleh jaringan PLN adalah menggunakan modul PV. Tujuan penelitian ini adalah untuk membandingkan efisiensi modul PV bahan monocrystalline dengan polycrystalline dan menemukan model estimasi karakteristik modul PV pada saat musim kemarau. Metode yang digunakan dalam penelitian ini adalah metode observasi yaitu melakukan pengukuran variabel SR, S, Isc dan Voc. Hasil penelitian menunjukkan bahwa modul PV monocrystalline lebih efisien dibandingkan dengan modul PV polycrystalline. Pada penggunaan modul PV monocrystalline, model estimasi persamaan regresi adalah $\mathrm{I}_{\mathrm{sc}}=0.0009 \mathrm{SR}+1.9497$ dan $\mathrm{V}_{\mathrm{oc}}=28.02-0.2683 \mathrm{~S}$. Pada penggunaan modul PV polycrystalline model estimasi persamaan regresi adalah $\mathrm{I}_{\mathrm{sc}}=0.001 \mathrm{SR}+1.6649$ dan $\mathrm{V}_{\mathrm{oc}}=25.644-0.2196 \mathrm{~S}$.
\end{abstract}

Kata kunci: Model estimasi, modul PV, monocrystalline, polycrystalline,

\section{PENDAHULUAN}

Masih terdapat 30,910 dari 78,011 rumah tangga di Kabupaten Kupang yang belum mendapatkan pasokan energi listrik dengan rasio elektrifikasi $60 \%$. Rata-rata rumah tangga yang belum mendapatkan pasokan energi listrik tersebut berada di perdesaan terpencil yang sulit dijangkau oleh jaringan [1], pada hal salah satu sumber penghasilan utama di perdesaan Kabupaten Kupang adalah dari hasil pertanian, selain untuk penerangan dimalam hari para petani sangat berharap dapat mengoperasikan pompa air listrik untuk mendapatkan air dari sumur-sumur karena curah hujan di Kabupaten tersebut relatif kecil sepanjang tahun.

Alternatif yang paling baik dalam penyediaan sumber energi listrik di perdesaan Kabupaten Kupang yang belum terjangkau oleh jaringan PLN adalah menggunakan modul Photovoltaic (modul PV) [2]. Intensitas radiasi sinar matahari di Kupang sangat optimum pada musim kemarau. Pada pagi, siang dan sore hari radiasi sinar matahari sangat berpengaruh terhadap luaran energi PLTS [3]. Perubahan intensitas sinar matahari dan sudut datang sinar matahari sangat berpengaruh terhadap tegangan yang diterima modul PV [4]. Kinerja modul PV berupa output daya maksimum bervariasi dengan musim. Pada akhir musim panas dan atau kemarau, suhu akan meningkat dan kinerja modul PV cenderung meningkat [5]. Namun demikian yang menjadi permasalahan penggunaan modul PV saat ini adalah memilih bahan PV yang tepat berdasarkan kondisi iklim terutama radiasi matahari dan suhu.

Penelitian ini mengkaji pengaruh radiasi matahari terhadap arus hubungan singkat dan juga pengaruh suhu terhadap tegangan rangkaian terbuka baik modul PV monocrystalline maupun polycrystalline sehingga para pengguna dan atau calon pengguna modul PV dapat memilih diantara kedua bahan modul PV tersebut.

Tujuan penelitian ini adalah untuk membandingkan efisiensi modul PV monocrystalline dan polycrystalline dan menemukan model estimasi karakteristik Modul PV monocrystalline maupun polycrystalline di Kabupaten Kupang pada saat musim kemarau, sehingga para pengguna modul PV dapat memilih bahan terbaik sesuai dengan kebutuhan. Selain keperluan pengguna modul PV khususnya di Kabupaten Kupang, hasil penelitian ini diharapkan bermanfaat bagi mahasiswa sebagai referensi dalam mengadakan praktikum pengujian karakteristik modul PV. 


\section{METODE PENELITIAN}

$\begin{array}{lll}\text { Metode yang digunakan untuk } & \text { adalah } \\ \text { memperoleh data sekunder } & \text { datarater } \\ \text { menggunakan metode study literature, }\end{array}$ sedangkan untuk mendapatkan data primer menggunakan metode observasi yaitu melakukan pengukuran variabel radiasi matahari (SR), suhu modul (S), arus hubung singkat (Isc) dan tegangan rangkaian terbuka (Voc). Pengukuran dilakukan secara bersamaan untuk bahan modul PV monocrystalline dan polycrystalline di Fenun 2 Desa Baumata Kecamatan Taebenu Kabupaten Kupang pada bulan Juli, Agustus dan September 2018. Alat yang digunakan dalam pengukuran antara lain adalah: 1 ) Solar power meter untuk mengukur radiasi matahari (Gambar 1). 2) Thermometer digital untuk mengukur suhu dibawah modul PV (Gambar 1). 3) Ampere meter digunakan untuk mengukur arus hubung singkat (Gambar 2). 4) Volt meter digital digunakan untuk mengukur tegangan rangkaian terbuka (Gambar 2). 5) Clinometer diguanakan untuk mengukur derajat kemiringan modul $\mathrm{PV}$ sebesar $10^{\circ}$ menghadap utara (Gambar 3) dan 6) Kompas digunakan untuk mengukur penempatan posisi modul PV menghadap utara (Gambar 3). Rakaian pengukuran modul PV disajikan pada Gambar 4. [6], [7].

Bahan utama yang digunakan dalam penelitian ini adalah dua unit modul PV $50 \mathrm{Wp}$ yang terdiri dari satu unit modul PV monocrystalline dan satu unit PV polycrystalline seperti disajikan pada Gambar 5 .

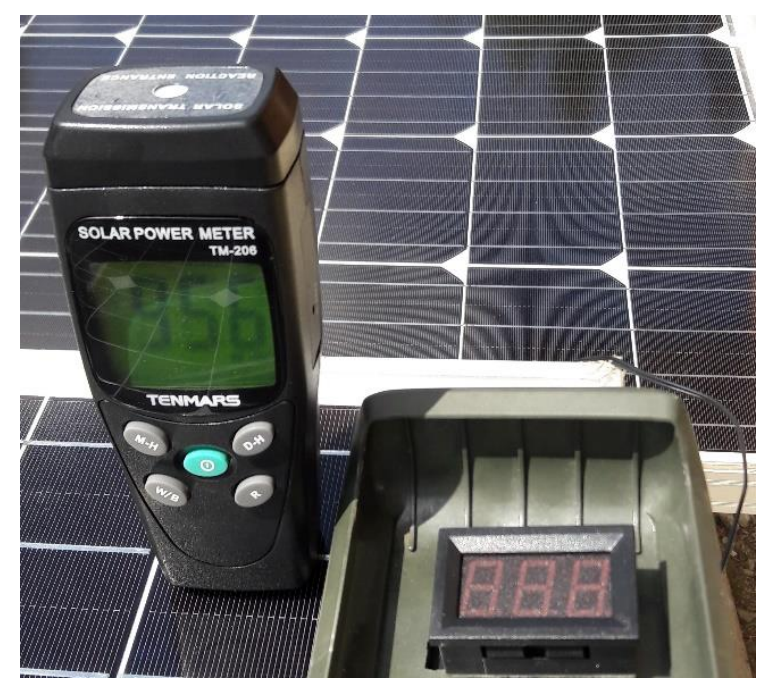

Gambar 1. Solar power meter dan thermometer digital

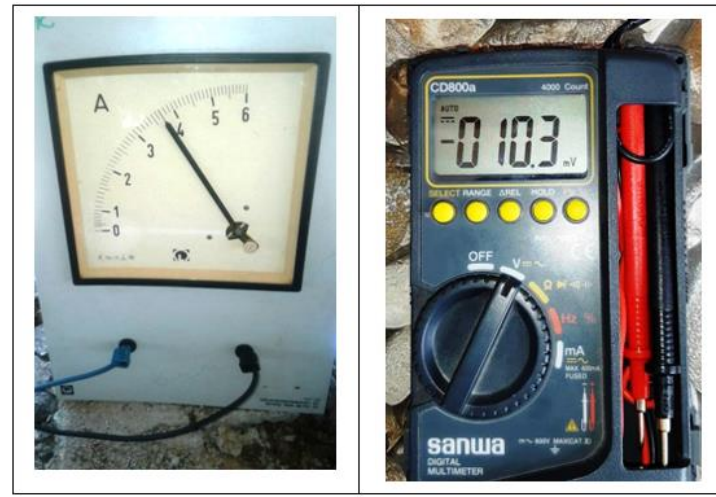

Gambar 2. Ampere meter dan volt meter
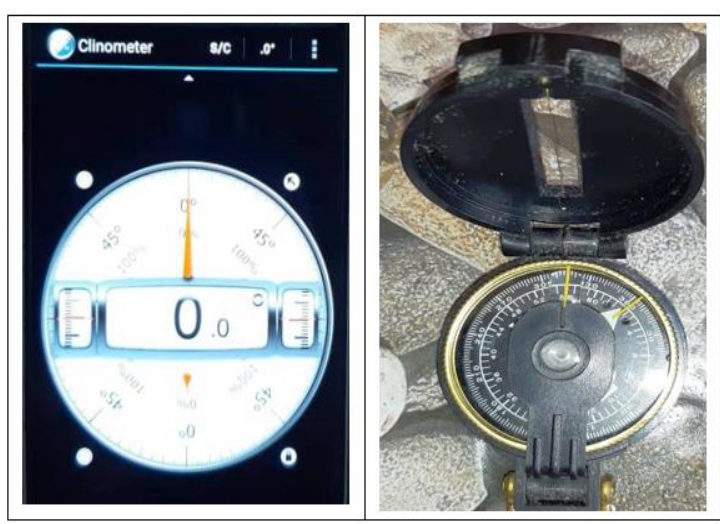

Gambar 3. Clinometer dan kompas

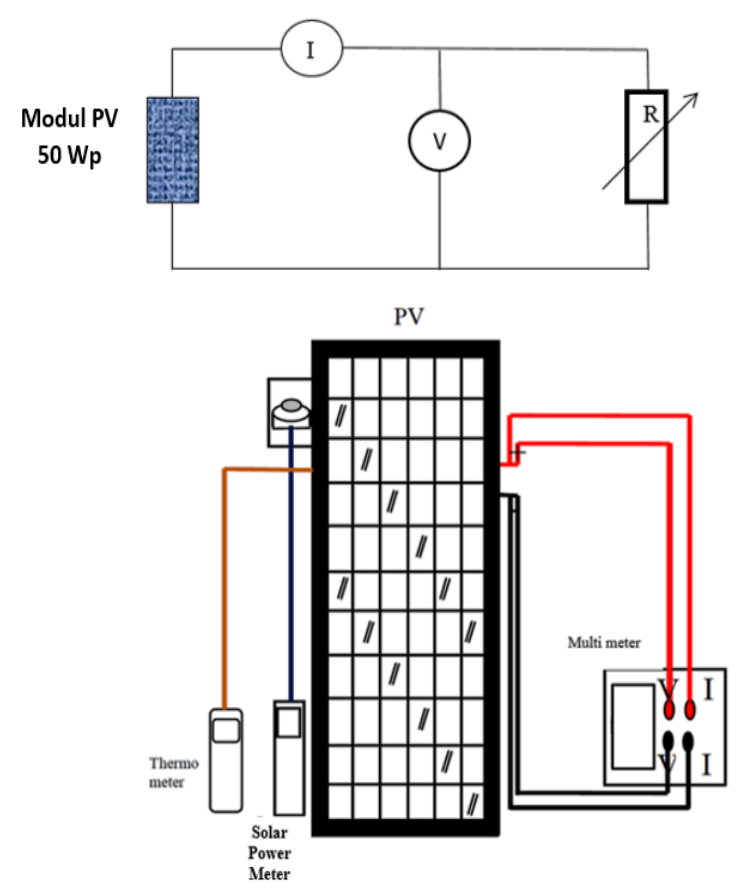

Gambar 4. Rangkaian pengukuran modul PV 


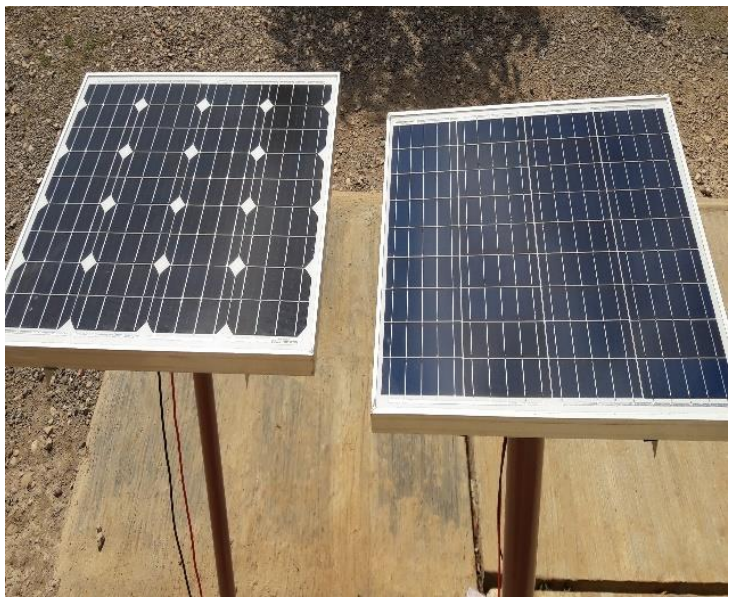

Gambar 5. Modul PV monocrystalline (kiri) dan polycrystalline (Kanan)

Metode analisis data yang digunakan untuk menemukan pengaruh radiasi matahari terhadap arus hubung singkat dan pengaruh suhu terhadap tegangan rangkaian terbuka menggunakan analisis regresi linier [8], sedangkan luaran daya modul PV yang merupakan arus hubung singkat (Isc) berbanding lurus dengan tegangan rangkin terbuka $\left(\mathrm{V}_{\mathrm{oc}}\right)$ pada modul $\mathrm{PV}$ dihitung menggunakan persamaan (1) [9]:

$P_{0}=I_{\text {sc. }} . V_{\text {oc }}$

Dimana:

Po : Daya output Solar PV (W)

$\mathrm{I}_{\mathrm{sc}} \quad$ : Arus hubung singkat $(\mathrm{A})$

$\mathrm{V}_{\mathrm{oc}} \quad$ : Tegangan rangkaian terbuka (V)

Besaran daya radiasi matahari yang datang sebagai daya input modul PV dapat dilakukan dengan perhitungan menggunakan persamaan (2).

$\mathrm{Pi}_{\mathrm{i}}=\mathrm{SR}$. AsPv.

Dimana:

$\mathrm{Pi}_{\mathrm{i}} \quad$ : Daya masuk ke panel surya (W)

Aspv : Luas permukaan Solar PV $\left(\mathrm{m}^{2}\right)$

$\mathrm{SR} \quad$ : Radiasiadiasi matahari $(\mathrm{W} / \mathrm{m} 2)$

Effisiensi Solar PV (П) dihitung dengan menggunakan persamaan (3)

$\eta=\frac{\mathrm{Po}}{\mathrm{Pi}} \times 100 \%$

Bagan alir penelitian disajikan pada Gambar 6.

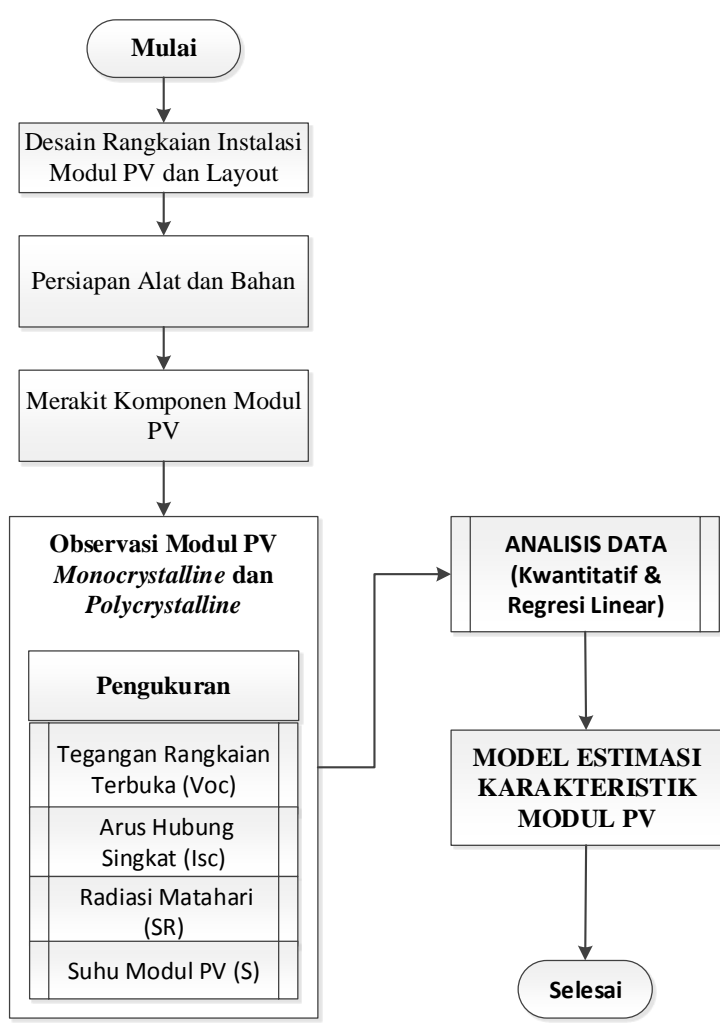

Gambar 6. Bagan alir penelitian

\section{HASIL DAN PEMBAHASAN}

Hasil yang ditampilakan dalam artikel ini untuk pengukuran radiasi matahari adalah pengukuran pada bulan Agustus 2018, dimana pada bulan Agustus tersebut adalah puncak radiasi mata hari tertinggi di Kabupaten Kupang sebesar $1,510 \mathrm{~W} / \mathrm{m}^{2}$. Pengukuran radiasi matahari tiga bulan terakhir di Kabupaten Kupang disajikan pada Gambar 7.

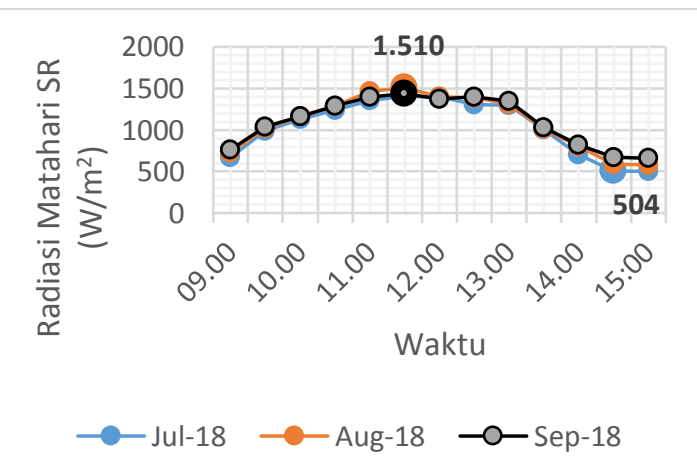

Gambar 7. Hasil pengukuran SR di Kabupaten Kupang

Hasil pengukuran variabel $V_{o c}, I_{s c}, S R$ dan $S$ pada modul PV monocrystalline menunjukkan bahwa $V_{\text {oc }}$ rata-rata 16.42 Volt, $I_{s c}$ rata-rata 2.96 Ampere, sedangkan SR rata-rata berada pada $1,098 \mathrm{~W} / \mathrm{m}^{2}$ dan SR maksimum berada pada pukul 11:30 Wita sebesar 1,510 $\mathrm{W} / \mathrm{m}^{2}$, sementara $\mathrm{S}$ rata-rata sebesar $43^{\circ} \mathrm{C}$ dan 
Rusman Sinaga ${ }^{1 \star}$, Marthen Dangu Elu Beily ${ }^{2}$

suhu modul PV tertinggi adalah $56^{\circ} \mathrm{C}$ pada pukul 11:30 dan 12.00 Wita. Hasil pengukuran variabel modul PV monocrystalline disajikan pada Tabel 1

Tabel 1. Hasil pengukuran variabel modul PV

\begin{tabular}{crrrr}
\multicolumn{5}{c}{ monocrystalline } \\
\hline Pukul & \multicolumn{4}{c}{ Variabel Pengukuran } \\
\cline { 2 - 5 }$($ WITA $)$ & $\mathrm{V}_{\mathrm{oc}}(\mathrm{V})$ & $\mathrm{I}_{\mathrm{sc}}(\mathrm{A})$ & $\mathrm{SR}\left(\mathrm{W} / \mathrm{m}^{2}\right)$ & $\mathrm{S}\left({ }^{\circ} \mathrm{C}\right)$ \\
\hline $9: 00$ & 18.00 & 2.50 & 732 & 36 \\
$9: 30$ & 18.00 & 2.70 & 1,025 & 36 \\
$10: 00$ & 19.00 & 3.50 & 1,164 & 37 \\
$10: 30$ & 19.50 & 3.20 & 1,291 & 37 \\
$11: 00$ & 19.50 & 3.30 & 1,464 & 37 \\
$11: 30$ & 13.50 & 3.50 & 1,510 & 56 \\
$12: 00$ & 13.00 & 3.30 & 1,400 & 56 \\
$12: 30$ & 15.50 & 3.00 & 1,391 & 46 \\
$13: 00$ & 14.50 & 2.90 & 1,318 & 48 \\
$13: 30$ & 17.00 & 2.80 & 1,017 & 42 \\
$14: 00$ & 15.00 & 2.70 & 801 & 49 \\
$14: 30$ & 16.00 & 2.60 & 586 & 44 \\
$15: 00$ & 15.00 & 2.50 & 580 & 38 \\
\hline Rata-rata & 16.42 & 2.96 & 1,098 & 43.23 \\
\hline
\end{tabular}

Hasil perhitungan daya output (Po) ratarata modul PV monocrystalline sebesar 48.67 Watt sedangkan daya input (Pi) rata-rata sebesar 397.60 Watt sehingga efisiensi modul PV rata-rata adalah $13 \%$. Hasil perhitungan variabel Po, Pi dan $\Pi$ disajikan pada Tabel 2.

Tabel 2. Hasil perhitungan efisiensi modul PV monocrystalline

\begin{tabular}{crrr}
\hline Pukul & \multicolumn{3}{c}{ Variabel Perhitungan } \\
\cline { 2 - 4 } (WITA) & Po(W) & Pi (W) & n (\%) \\
\hline 9:00 & 45.00 & 265.01 & $17 \%$ \\
9:30 & 48.60 & 371.01 & $13 \%$ \\
$10: 00$ & 66.50 & 421.37 & $16 \%$ \\
$10: 30$ & 62.40 & 467.34 & $13 \%$ \\
$11: 00$ & 64.35 & 530.01 & $12 \%$ \\
$11: 30$ & 47.25 & 546.62 & $9 \%$ \\
$12: 00$ & 42.90 & 506.80 & $8 \%$ \\
$12: 30$ & 46.50 & 503.51 & $9 \%$ \\
$13: 00$ & 42.05 & 477.01 & $9 \%$ \\
$13: 30$ & 47.60 & 368.15 & $13 \%$ \\
$14: 00$ & 40.50 & 289.96 & $14 \%$ \\
$14: 30$ & 41.60 & 212.01 & $20 \%$ \\
$15: 00$ & 37.50 & 209.96 & $18 \%$ \\
\hline Rata-rata & 48.67 & 397.60 & $13 \%$ \\
\hline
\end{tabular}

Hasil pengukuran variabel $V_{o c}, I_{s c}, S R$ dan $S$ pada modul PV bahan polycrystalline menunjukkan bahwa $V_{\text {oc }}$ rata-rata 15 Volt, Isc rata-rata 2.75 Ampere, sedangkan SR rata-rata berada pada $1,098 \mathrm{~W} / \mathrm{m}^{2}$ dan SR maksimum berada pada pukul 11:30 Wita sebesar 1,510 $\mathrm{W} / \mathrm{m}^{2}$, sementara $S$ rata-rata sebesar $48^{\circ} \mathrm{C}$ dan suhu modul PV tertinggi adalah $56^{\circ} \mathrm{C}$ pada pukul 10:00 dan 12.00 Wita. Hasil pengukuran variabel modul PV polycrystalline disajikan pada Tabel 3.
Tabel 3. Hasil pengukuran variabel modul PV polycrystalline

\begin{tabular}{ccrrr}
\hline Pukul & \multicolumn{4}{c}{ Variabel Pengukuran } \\
\cline { 2 - 5 }$($ WITA $)$ & $\mathrm{V}_{\text {oc }}(\mathrm{V})$ & $\mathrm{I}_{\mathrm{sc}}(\mathrm{A})$ & $\mathrm{SR}\left(\mathrm{W} / \mathrm{m}^{2}\right)$ & $\mathrm{S}\left({ }^{\circ} \mathrm{C}\right)$ \\
\hline $9: 00$ & 16.00 & 2.30 & 732 & 38 \\
$9: 30$ & 17.00 & 2.85 & 1,025 & 40 \\
$10: 00$ & 13.00 & 3.10 & 1,164 & 56 \\
$10: 30$ & 13.00 & 3.07 & 1,291 & 55 \\
$11: 00$ & 13.50 & 3.08 & 1,464 & 55 \\
$11: 30$ & 13.50 & 3.09 & 1,510 & 56 \\
$12: 00$ & 13.50 & 3.00 & 1,400 & 54 \\
$12: 30$ & 14.00 & 2.93 & 1,391 & 53 \\
$13: 00$ & 14.50 & 2.85 & 1,318 & 51 \\
$13: 30$ & 15.50 & 2.67 & 1,017 & 48 \\
$14: 00$ & 17.00 & 2.38 & 801 & 43 \\
$14: 30$ & 17.50 & 2.35 & 586 & 42 \\
$15: 00$ & 17.00 & 2.09 & 580 & 37 \\
\hline Rata-rata & 15.00 & 2.75 & $1,098.34$ & 48.47 \\
\hline
\end{tabular}

Hasil perhitungan daya output (Po) ratarata modul PV polycrystalline sebesar 40.76 Watt sedangkan daya input $(\mathrm{Pi})$ rata-rata sebesar 397.60 Watt sehingga efisiensi modul PV rata-rata adalah $11 \%$. Hasil perhitungan variabel Po, Pi dan $\Pi$ disajikan pada Tabel 4.

Tabel 4. Hasil perhitungan efisiensi modul PV polycrystalline

\begin{tabular}{crrr}
\hline Pukul & \multicolumn{3}{c}{ Variabel Perhitungan } \\
\cline { 2 - 4 } (WITA) & $\mathrm{Po}(\mathrm{W})$ & $\mathrm{Pi}(\mathrm{W})$ & $\eta(\%)$ \\
\hline $9: 00$ & 36.80 & 265.01 & $14 \%$ \\
$9: 30$ & 48.45 & 371.01 & $13 \%$ \\
$10: 00$ & 40.30 & 421.37 & $10 \%$ \\
$10: 30$ & 39.90 & 467.34 & $9 \%$ \\
$11: 00$ & 41.58 & 530.01 & $8 \%$ \\
$11: 30$ & 41.71 & 546.62 & $8 \%$ \\
$12: 00$ & 40.54 & 506.80 & $8 \%$ \\
$12: 30$ & 40.97 & 503.51 & $8 \%$ \\
$13: 00$ & 41.28 & 477.01 & $9 \%$ \\
$13: 30$ & 41.35 & 368.15 & $11 \%$ \\
$14: 00$ & 40.39 & 289.96 & $14 \%$ \\
$14: 30$ & 41.05 & 212.01 & $19 \%$ \\
15:00 & 35.53 & 209.96 & $17 \%$ \\
\hline Rata-rata & 40.76 & 397.60 & $\mathbf{1 1 \%}$ \\
\hline
\end{tabular}

Berdasarkan fenomena radiasi matahari di Kabupaten Kupang Hasil perhitungan efisiensi modul PV (П) menunjukkan bahwa penggunaan modul PV monocrystalline lebih efisien dibandingkan dengan modul PV polycrystalline, dimana rata-rata efisiensi modul PV monocrystalline 13\% sedangkan modul PV polycrystalline sebesar $11 \%$. Karakteristik efisiensi Modul PV terhadap waktu disajikan pada Gambar 8. 


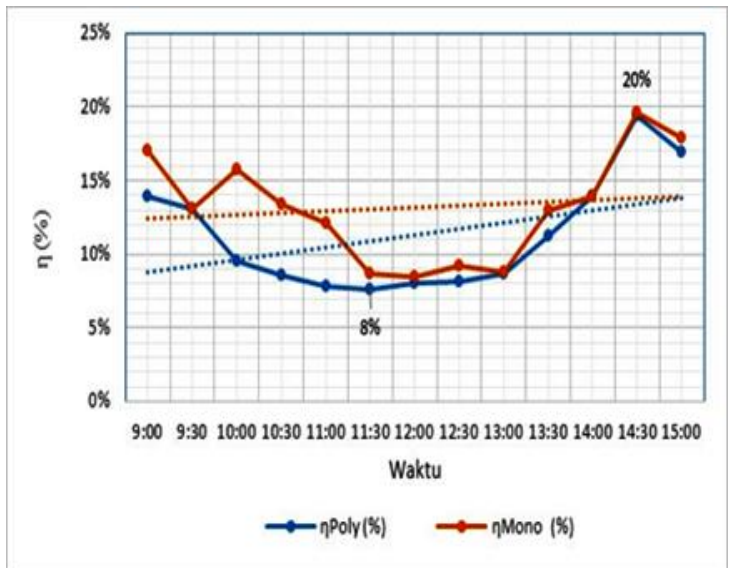

Gambar 8. Karakteristik efisiensi modul PV terhadap Waktu

Pada penggunaan modul PV monocrystalline, setiap kenaikan radiasi Matahari (SR) $1 \mathrm{~W} / \mathrm{m}^{2}$, maka arus hubung singkat modul PV $\left(\mathrm{I}_{\mathrm{sc}}\right)$ akan bertambah 0.0009 Amper. Model estimasi persamaan regresi $\mathrm{I}_{\mathrm{sc}}=$ $0.0009 \mathrm{SR}+1.9497$ dengan $\mathrm{R}^{2}=71 \%$, artinya $71 \%$ Isc $_{\text {sc }}$ dipengaruhi oleh radiasi matahari dan $29 \%$ dipengaruhi oleh variabel lainnya. Model estimasi pengaruh SR terhadap Isc modul PV monocrystalline disajikan pada Gambar 9.

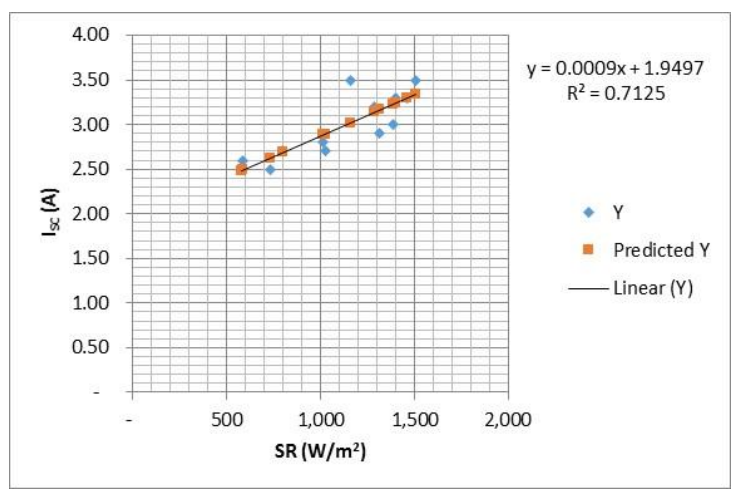

Gambar 9. Model estimasi pengaruh SR terhadap Isc modul PV monocrystalline

Pada penggunaan modul PV polycrystalline setiap kenaikan radiasi matahari (SR) $1 \mathrm{~W} / \mathrm{m}^{2}$, maka arus hubung singkat modul PV $\left(I_{s c}\right)$ akan bertambah 0.001 Ampere. Model estimasi persamaan regresi $\mathrm{I}_{\mathrm{sc}}=0.001 \mathrm{SR}+$ 1.6649 dengan $\mathrm{R}^{2}=86 \%$, artinya $86 \% \mathrm{I}_{\mathrm{sc}}$ dipengaruhi oleh radiasi matahari dan $14 \%$ dipengaruhi oleh variabel lainnya. Model estimasi pengaruh SR terhadap Isc modulı PV polycrystalline disajikan pada Gambar 10 .

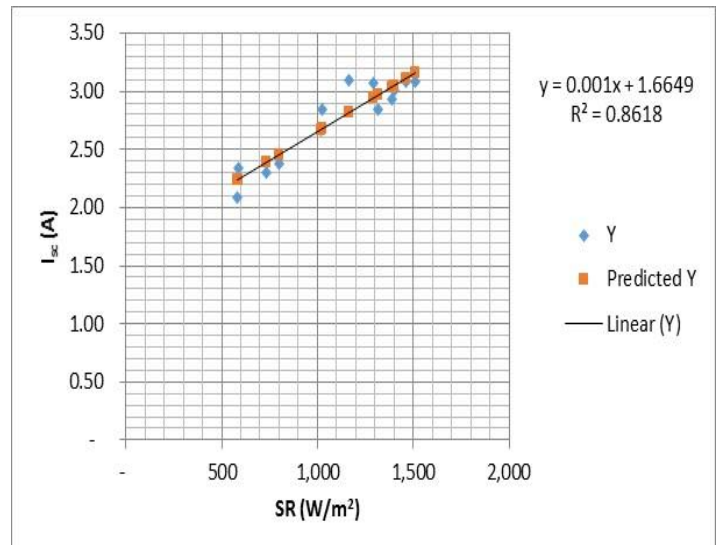

Gambar 10. Model estimasi pengaruh SR terhadap Isc modul PV polycrystalline

Pada penggunaan modul PV monocrystalline, setiap kenaikan suhu modul PV sebesar $1^{\circ} \mathrm{C}$, maka tegangan rangkaian terbuka $\left(\mathrm{V}_{\mathrm{oc}}\right)$ akan turun 0.2683 Volt. Model estimasi persamaan regresi $\mathrm{V}_{\mathrm{oc}}=28.02$ $0.2683 \mathrm{~S}$, dengan $\mathrm{R}^{2}=77 \%$, artinya $77 \% \mathrm{~V}_{\mathrm{oc}}$ dipengaruhi oleh suhu modul PV dan $23 \%$ dipengaruhi oleh variabel lainnya. Model estimasi pengaruh $\mathrm{S}$ terhadap $\mathrm{V}_{\mathrm{oc}}$ modul $\mathrm{PV}$ monocrystalline disajikan pada Gambar 11 .

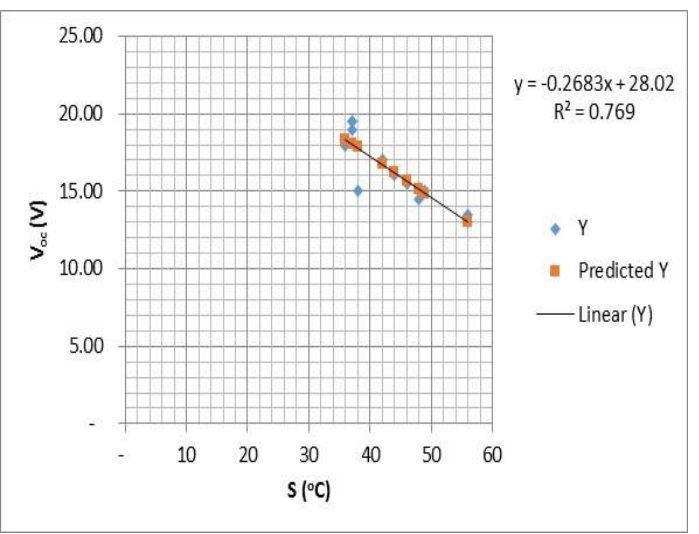

Gambar 11. Model estimasi pengaruh $S$ terhadap $\mathrm{V}_{\mathrm{oc}}$ modul PV monocrystalline

Pada penggunaan modul PV polycrystalline, setiap kenaikan suhu modul PV sebesar $1^{\circ} \mathrm{C}$, maka tegangan rangkaian terbuka $\left(\mathrm{V}_{\mathrm{oc}}\right)$ akan turun 0.2196 Volt. Model estimasi persamaan regresi $\mathrm{V}_{\mathrm{oc}}=25.644$ $0.2196 \mathrm{~S}$, dengan $\mathrm{R}^{2}=87 \%$, artinya $87 \% \mathrm{~V}_{\mathrm{oc}}$ dipengaruhi oleh suhu modul PV dan $13 \%$ dipengaruhi oleh variabel lainnya. Model estimasi pengaruh $\mathrm{S}$ terhadap $\mathrm{V}_{\text {oc }}$ modul PV polycrystalline disajikan pada Gambar 12. 


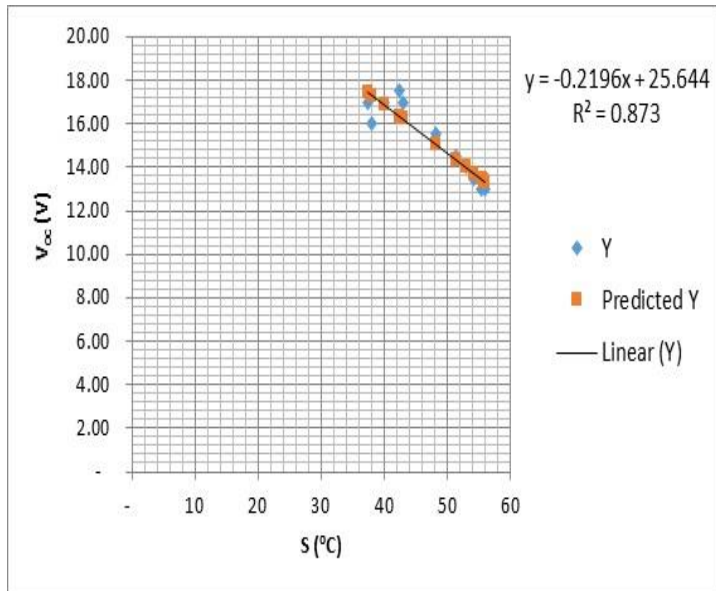

Gambar 12. Model estimasi pengaruh S terhadap $\mathrm{V}_{\text {oc }}$ modul PV polycrystalline

\section{PENUTUP}

\section{KESIMPULAN}

Berdasarkan fenomena radiasi matahari di Kabupaten Kupang modul PV $50 \mathrm{Wp}$ monocrystalline lebih efisien dibandingkan dengan modul PV polycrystalline. Efisiensi ratarata modul PV monocrystalline 13\% sedangkan modul PV polycrystalline $11 \%$.

Pada penggunaan modul PV monocrystalline, model estimasi persamaan regresi adalah $\mathrm{I}_{\mathrm{sc}}=0.0009 \mathrm{SR}+1.9497$ dan $\mathrm{V}_{\mathrm{oc}}$ $=28.02-0.2683 \mathrm{~S}$. Pada penggunaan modul PV polycrystalline model estimasi persamaan regresi adalah $\mathrm{I}_{\mathrm{sc}}=0.001 \mathrm{SR}+1.6649$ dan $\mathrm{V}_{\mathrm{oc}}$ $=25.644-0.2196 \mathrm{~S}$.

\section{SARAN}

Berdasarkan fenomena perubahan iklim di Indonesia yang selalu mengalami perubahan, maka radiasi matahari juga akan berubah sesuai dengan kondisi iklim tersebut, sehingga perlu dilakukan penelitian sepanjang tahun untuk mendapatkan data series minimal lima tahun terakhir, sehingga dapat dilakukan pemodelan dinamis untuk memprediksi radiasi matahari sampai sepuluh tahun kedepan.

\section{DAFTAR PUSTAKA}

[1] R. Sinaga, Prastowo, B. C. H. Simangunsong, A. Liebman, and A. H. Tambunan, "Analysis of barriers in supplying electricity using interpretative structural modeling," Energy Strateg Rev, vol. 25, pp. 11-17, 2019.

[2] R. Sinaga, A. Halomoan Tambunan, P. Prastowo, and B. C. Hamonangan Simangunsong, "Analisis Alternatif Solusi Penyediaan Sumber Energi Listrik Studi Kasus: Kabupaten
Kupang," J Keteknikan Pertan, vol. 05, no. 3, pp. 283-290, 2017.

[3] R. Sinaga, "Pengaruh Parameter Lingkungan dan Penempatan Posisi Modul Terhadap Luaran Energi PLTS Menggunakan Solar Cell $50 \mathrm{Wp}, 12$ Volt," Stud Teknol, vol. 4, no. 2, pp. 178187, 2011.

[4] S. Bahari and A. Laka, "Pengaruh Perubahan Arah Sudut Sel Surya Terhadap Tegangan," in Seminar Nasional Sains dan Teknologi 2017, 2017, no. November, pp. 1-4.

[5] J. Tanesab, D. Parlevliet, J. Whale, and T. Urmee, "Dust Effect and its Economic Analysis on PV Modules Deployed in a Temperate Climate Zone," in Energy Procedia, 2016, vol. 100, pp. 65-68.

[6] Yanuar, L. Umar, R. N, and Setiadi, "Evaluasi Nilai Tahanan Internal Modul Panel Fotovoltaik (PV) Berdasarkan Pemodelan Kurva I (V) Normal Light Dan Dark Current," in Presiding Seminar Nasional Fisiika Terapan III Departemen Fisika, FST, Universitas Airlangga Surabaya, 2012, no. 15 September, pp. 978-979.

[7] A. A. Tino, "Dampak Debu Terhadap Kinerja Modul Photovoltaik di Kampus Politeknik Negeri Kupang," Flash, pp. 26-33, 2016.

[8] J. Harlan, Analisis Regresi Linear. Depok: Gunadarma, 2018.

[9] R. A. M. Napitupulu, S. Simanjuntak, and S. Sibarani, "Pengaruh Material Monokristal Dan Polikristal Terhadap Karakteristik Sel Surya 20 Wp dengan Trackingsistem Dua Sumbu," Medan, 2017. 